\title{
Peran Masyarakat Dalam Mewujudkan Desa Wisata: Studi di Kampung Nelayan, Tanjung Binga, Kabupaten Belitung
}

\author{
Ilham Junaid* \\ Politeknik Pariwisata Makassar, Indonesia \\ Email: illank77@yahoo.co.id
}

\begin{abstract}
This paper aims at analyzing the opportunities for managing and developing Kampung Nelayan as Desa wisata tourism village); 2) recommending efforts or steps to optimize the role and function of the community in managing tourism village. This paper employed a qualitative methodology in understanding and analyzing the actual condition of Kampung Nelayan through interviews and observation. The research was done in 2019 by visiting the research area. The research shows that Kampung Nelayan in Belitung Regency has the potential as a tourism village. Cultural tourism, with an emphasis on community-based rural tourism, is essential to attract visitors. The hospitality of the local people is an important factor in supporting the implementation of community-based rural tourism. This paper proposes the role of the local community for the implementation of a tourism village, including the initiator, executor, and evaluator. The local community, as the stakeholder of tourism, may implement stages (functions) such as socialization, economic, participation, and mutual support to achieve the goals of tourism village.
\end{abstract}

Keywords: Kampung Nelayan, Belitung Regency, tourism village, rural tourism, the role of community, CBT

\begin{abstract}
Abstrak
Tujuan penelitian ini adalah untuk 1) menganalisis peluang pengelolaan dan pengembangan Kampung Nelayan di Kabupaten Belitung sebagai desa wisata.; 2) mengusulkan optimalisasi peran dan fungsi masyarakat dalam mewujudkan desa wisata di Kampung Nelayan. Penelitian ini menggunakan pendekatan kualitatif dalam memahami dan menganalisis kondisi faktual di Kampung Nelayan dengan melakukan wawancara, observasi dan studi kepustakaan. Penelitian dilaksanakan pada tahun 2019 dengan kunjungan ke Kampung Nelayan. Hasil penelitian menunjukkan bahwa Kampung Nelayan di Kabupaten Belitung dapat diwujudkan sebagai desa wisata berbasis masyarakat. Potensi budaya masyarakat pesisir serta keramahtamahan penduduknya adalah peluang untuk mengoptimalkan potensi pariwisata melalui konsep desa wisata. Penelitian ini mengusulkan peran masyarakat untuk pengelolaan desa wisata yakni sebagai penggagas (inisiator), pelaksana (executor) dan evaluator. Penelitian ini juga merekomendasikan pentingnya menerapkan empat atau fungsi agar desa wisata sebagai sistem dapat berjalan dengan baik yakni, fungsi sosialisasi, fungsi ekonomi, partisipasi dan dukungan masyarakat.
\end{abstract}

Kata Kunci: Kampung Nelayan; Kabupaten Belitung; desa wisata, peran masyarakat; pariwisata berbasis masyarakat 


\section{A. PENDAHULUAN}

Pengelolaan dan pengembangan desa wisata menjadi salah satu pilihan dan strategi pemerintah Republik Indonesia melalui Kementerian Pariwisata dan Ekonomi Kreatif dalam mendorong masyarakat sebagai pelaku utama pariwisata. Suatu desa memiliki potensi wisata yang layak untuk dikembangkan untuk kepentingan masyarakat di desa tersebut. Hal ini tergantung dari kesiapan anggota masyarakat dalam mengelola potensi yang ada serta keinginan menerima pariwisata sebagai suatu aktifitas perekonomian.

Tujuan tersebut belum sepenuhnya dapat diwujudkan secara optimal. Terdapat berbagai alasan atau faktor penentu terwujudnya desa wisata, salah satunya adalah masyarakat. Masyarakat merupakan salah satu unsur penting dari suatu pemangku kepentingan (stakeholder) di destinasi pariwisata. Masyarakat dapat menjadi penggerak dan cikal bakal jika suatu desa akan dikelola dan dikembangkan melalui konsep desa wisata. Tujuan ini dapat diwujudkan di Kampung Nelayan yang berlokasi di Kabupaten Belitung. Belitung merupakan salah satu destinasi utama yang memiliki potensi wisata dan dapat memberikan kontribusi positif bagi peningkatan perekonomian masyarakat khususnya di daerah atau wilayah pedesaan.

Wisata pedesaan (rural tourism) dan desa wisata atau tourism village adalah dua istilah yang cenderung memiliki perbedaan namun memiliki kesamaan dalam hal pemanfaatan desa sebagai aset pariwisata. Segala potensi desa yang memiliki keunikan dan dapat menjadi daya tarik wisata menjadi alasan wisatawan untuk menjadikan desa sebagai tujuan melakukan perjalanan. Rural tourism telah menjadi bagian penting di hampir setiap negara di dunia dan berkontribusi terhadap perekonomian suatu negara (Junaid, et. al, 2020; Sharpley, 2002). Dalam konteks penelitian ini, istilah rural tourism ataupun tourism village adalah istilah yang sama karena pemanfaatan desa sebagai aset utama pariwisata. Kenyataannya, tidak banyak desa telah dikelola dengan pengemasan desa wisata atau wisata pedesaan. Ezeuduji dan Rid (2011:189) mengemukakan "not every rural area can benefit equally from the increasing demand in rural tourism". Desa yang ada di destinasi pariwisata belum sepenuhnya belum mendapatkan manfaat secara merata dari meningkatnya rural tourism. Tourism village ataupun rural tourism perlu mendapat perhatian dengan memaksimalkan peran stakeholder untuk dapat terlibat secara aktif dalam mengelola potensi desa.

Kampung Nelayan di Kabupaten Belitung adalah suatu wilayah yang telah menjadi lokasi para nelayan melangsungkan hidupnya melalui aktifitas menangkap ikan. Terdapat 3 (tiga) isu yang menjadi latar belakang pentingnya melakukan penelitian dalam konteks fungsi dan peran masyarakat dalam mewujudkan desa wisata. Pertama, Kampung Nelayan telah dikunjungi oleh wisatawan mancanegara dan domestik dengan tujuan melihat aktifitas perikanan masyarakat. Namun, kegiatan pariwisata belum menjadi pilihan utama bagi masyarakat. Artinya, masyarakat hanya menjadi objek dan belum menjadi pelaku kepariwisataan. Kedua, Kampung Nelayan telah dipromosikan oleh pemerintah daerah sebagai daya tarik wisata. Namun, secara kelembagaan, Kampung Nelayan di Belitung belum dikelola secara optimal dalam konteks tata kelola desa wisata yang baik. Ketiga, masyarakat di Kampung Nelayan dapat mencari alternatif aktifitas perekonomian, salah satunya melalui kegiatan kepariwisataan.

Priyanto dan Safitri (2016) mengkaji desa wisata di Jawa Tengah. Hasil penelitian mereka menunjukkan bahwa terdapat tiga permasalahan dalam membangun desa wisata berbasis budaya yakni belum optimalnya kualitas sumber daya manusia, sarana dan prasarana dan promosi. Desa Wisata Pampang di Samarinda juga menunjukkan minimnya pengorganisasian komunitas (Putra, 2013). Sunarjaya, Antara dan Prasiasa (2018) mengemukakan bahwa ketiadaan rencana pengembangan pariwisata di desa wisata (khususnya di Desa Wisata Munggu, Badung) merupakan kendala dalam pengembangan potensi wisata. Tiga hasil penelitian tersebut menunjukkan bahwa 
desa wisata telah dikaji oleh akademisi dalam berbagai perspektif. Perbedaan dalam penelitian ini adalah bahwa Kampung Nelayan memiliki karakteristik tersendiri dalam pola pengembangan desa wisata. Karena itu, penelitian ini difokuskan pada bagaimana mengoptimalkan peran dan fungsi masyarakat dalam konteks desa wisata.

Penelitian ini bertujuan untuk 1) menganalisis peluang pengelolaan dan pengembangan Kampung Nelayan sebagai Desa Wisata di Kabupaten Belitung; 2) mengusulkan optimalisasi peran dan fungsi masyarakat dalam mewujudkan Desa Wisata di Kampung Nelayan, Kabupaten Belitung. Sejalan dengan tujuan penelitian tersebut, penulis dituntun oleh rumusan masalah penelitian, 1) Apa potensi dan peluang Kampung Nelayan untuk diwujudkan sebagai desa wisata; 2) Bagaimana peran dan fungsi masyarakat dalam mewujudkan pengelolaan dan pengembangan Kampung Nelayan sebagai desa wisata. Penelitian ini merupakan kajian penulis dalam melihat eksistensi Kampung Nelayan di Kabupaten Belitung agar dikelola berdasarkan prinsip pariwisata berbasis masyarakat dengan menjadikan masyarakat sebagai aktor utama yang menjalankan fungsi unit sosial dan sistem yang saling berpengaruh.

\section{B. KAJIAN PUSTAKA}

\section{Fungsi dan Peran Masyarakat Sebagai Penopang Desa Wisata}

Masyarakat (community) diartikan sebagai gabungan dari berbagai unit sosial dan sistem yang memungkinkan para anggota dalam suatu komunitas melakukan aktifitas dalam rangka memenuhi kebutuhan hidupnya sehari-hari (Wall, 2000). Anggota masyarakat yang tergolong sebagai komunitas bekerja secara bersama dan mandiri dalam rangka upaya mempertahankan hidupnya melalui kegiatan perekonomian. Masyarakat (community) memiliki batas atau cakupan sehingga menghasilkan suatu aktifitas sosial. Pertama, anggota masyarakat berada dalam satu wilayah geografis. Kedua, masyarakat saling membutuhkan satu sama lain interaksi yang terbangun merupakan ciri khas terwujudnya aktifitas sosial. Ketiga, masyarakat memiliki norma atau aturan yang mengikat sehingga para anggota masyarakat mengikuti aturan tersebut.

Desa wisata adalah salah satu wujud aktifitas sosial yang melibatkan beberapa anggota masyarakat yang bekerja secara bersama. Desa wisata dijalankan tidak hanya berdasarkan prinsip kemandirian satu atau beberapa elemen masyarakat, tetapi melibatkan berbagai unsur. Keberhasilan desa wisata dengan tingkat kunjungan yang meningkat serta manfaat ekonomis yang diperoleh masyarakat adalah hasil kerja bersama dari berbagai elemen. Karena itu, kerja sama yang dijalankan oleh masyarakat merupakan aktifitas beberapa unit sosial.

Wall (2000) mengemukakan 5 (lima) fungsi utama yang akan dijalankan oleh masyarakat sebagai unit sosial dan sebagai sistem yakni fungsi ekonomi (economic), fungsi sosialisasi (socialisation), fungsi kontrol sosial (social control), fungsi partisipasi dan fungsi saling mendukung. Fungsi ekonomi diartikan sebagai peran anggota masyarakat dalam menghasilkan, mendistribusikan dan konsumsi produk yang dihasilkan. Fungsi sosialisasi diartikan sebagai peran anggota masyarakat yang saling membutuhkan dalam upaya memenuhi kebutuhannya. Fungsi kontrol sosial berarti apa yang menjadi aktifitas masyarakat senantiasa mendapat kontrol dari masyarakat itu sendiri. Selanjutnya, anggota masyarakat akan berpartisipasi dalam berbagai aktifitas sehingga menjadi bagian dari komunitas tersebut. Setiap anggota masyarakat dapat menjadi pendukung dari aktifitas yang dijalankan oleh masyarakat.

Manfaat yang didapatkan masyarakat ketika aktif dalam kegiatan pariwisata telah menjadi alasan para akademisi untuk mengusulkan partisipasi aktif masyarakat dalam kegiatan pariwisata. Kualitas kehidupan masyarakat dari sisi perekonomian serta peluang untuk memperoleh pekerjaan dapat terwujud (Matarrita-Cascante 2010; Nicely dan Sydnor, 2015). Nicely dan Sydnor 
telah melakukan penelitian di Jamaica mengenai dampak positif yang dihasilkan pariwisata. Dampak positif tersebut mendorong masyarakat untuk semakin aktif dalam kegiatan pariwisata. Sebaliknya, terdapat peluang bagi masyarakat untuk tidak terlibat jika mereka tidak memahami manfaat pariwisata.

\section{Pariwisata Berbasis Masyarakat}

Pariwisata berbasis masyarakat atau community-based tourism (CBT) telah menjadi perhatian dari para pemangku kepentingan di destinasi pariwisata di dunia termasuk di Indonesia. Pemerintah daerah di Indonesia menerima dan mengadopsi konsep CBT dalam upaya mengembangkan pariwisata di daerahnya masing-masing. Konsep CBT pertama kali muncul pada tahun 70-an sebagai upaya untuk mengatasi dan merespon munculnya dampak negatif yang dihasilkan dari aktifitas pariwisata yang bersifat masif (Hall dan Lew, 2009; Murphy, 1985; Zapata, Hall, Lindo dan Vanderschaeghe, 2011). Menurut Zapata et al (2011), konsep CBT lebih banyak dimanfaatkan pada konteks masyarakat di daerah pedesaan dan dengan tujuan untuk mengupayakan terwujudnya ekowisata. Namun, sejalan dengan kebutuhan setiap destinasi dan tujuan dari CBT, maka konsep tersebut telah menjadi pilihan dari stakeholder pariwisata khususnya pemerintah di tingkat kabupaten dan kota di Indonesia.

Pariwisata berbasis masyarakat dapat sukses jika memenuhi beberapa unsur atau kriteria. Kibicho (2008) mengemukakan 5 (lima) kunci sukses untuk menerapkan dan mencapai tujuan pariwisata berbasis masyarakat. Pertama, CBT perlu melibatkan para pemangku kepentingan (stakeholder) (Beeton, 2006; Hiwasaki, 2006; Manyara \& Jones, 2007). Dalam konteks studi pariwisata, stakeholder dapat mencakup wisatawan, masyarakat, pemerintah, industri atau pelaku pariwisata. Dalam konteks Indonesia, stakeholder dapat mengacu pada konsep pentaheliks pariwisata yang terdiri dari akademisi, pemerintah, industri atau bisnis, masyarakat dan media.

Faktor kedua adalah kejelasan tujuan dan sasaran yang akan dicapai. Tujuan penerapakan konsep CBT harus jelas tertuang sehingga setiap stakeholder senantiasa mengacu pada tujuan yang hendak dicapai. Faktor ketiga adalah kejelasan manfaat yang akan diperoleh apakah apakah manfaat yang diperuntukkan untuk individu ataupun manfaat secara bersama. Faktor keempat adalah dibutuhkan pengelola, pemimpin atau koordinator yang memungkinkan terwujudnya kegiatan melalui peran pemimpin tersebut. Faktor kelima adalah komitmen setiap stakeholder yang terlibat untuk mengimplementasikan keputusan yang diambil (Aas, Ladkin \& Fletcher, 2005). Komitmen ini merupakan hasil pemikiran secara bersama dan akan dijalankan secara bersama.

\section{Konsep Desa Wisata dan Wisata Pedesaan (Rural Tourism)}

Wisata pedesaan (rural tourism) adalah jenis pariwisata yang mengalami pertumbuhan di banyak destinasi di dunia. Wisata pedesaan (termasuk desa wisata) dapat memberikan kesempatan bagi penduduknya untuk memperoleh pekerjaan (Petrzelka, et., 2005; Ezeuduji, dan Rid, 2011). Rural tourism adalah jenis atau tipe pariwisata yang baru dan relevan dalam upaya mengembangkan desa dengan berbagai potensi yang dimiliki (Campón-Cerro, A. M., HernándezMogollón, dan Alves, 2017). Rural tourism muncul karena adanya realita modernisasi dan urbanisasi dan adanya perubahan lansekap alam (Farrell dan Russell, 2011; Hall, Mitchell dan Roberts, 2016; Murdoch, 2003). Rural tourism dan desa wisata pada prinsipnya memiliki tujuan dan konsep yang sama yakni upaya mengelola potensi desa untuk memberikan nilai manfaat ke masyarakat melalui konsep desa wisata.

Dengan adanya tren perkembangan desa wisata, mendorong setiap desa untuk memanfaatkan potensi yang dimiliki untuk menjadi desa wisata. Untuk mewujudkan desa wisata, terdapat 2 (dua) unsur penting yang perlu ada yakni, akomodasi dan atraksi (Dewi, Fandeli dan Baiquni, 2013). Akomodasi di pedesaan dapat memanfaatkan rumah penduduk sebagai salah satu tempat untuk digunakan oleh wisatawan melalui konsep homestay. Pengelolaan homestay merupakan salah satu cara atau bentuk pengelolaan desa berbasis masyarakat (Junaid dan Salim, 
2019). Atraksi memberikan kesempatan kepada wisatawan untuk melihat kehidupan masyarakat desa baik yang berkaitan dengan kebudayaannya maupun alamnya. Dalam konteks penelitian ini, masyarakat adalah salah unsur penting dalam mewujudkan desa wisata.

Masyarakat dikategorikan sebagai salah bagian dari pemangku kepentingan (stakeholder) pariwisata. Junaid dan Salim (2019) mengemukakan bahwa keberhasilan pengelolaan desa wisata tidak terlepas dari anggota masyarakat yang ada di suatu desa. Bagi masyarakat yang mengelola desa wisata, dibutuhkan strategi untuk melibatkan anggota masyarakat dari desa tersebut. Embacher (2016) mengemukakan pentingnya manajemen strategis (strategic management) dengan pelibatan anggota masyarakat.

\section{METODE PENELITIAN}

Penelitian ini menerapkan prinsip metodologi penelitian kualitatif dengan melakukan kunjungan langsung ke lokasi penelitian. Penelitian dilaksanakan di Kampung Nelayan, Kabupaten Belitung Provinsi Belitung dengan 2 (dua) kali kunjungan di bulan Oktober tahun 2019. Pengumpulan data difokuskan pada masyarakat yang bekerja sebagai nelayan dan menyatakan kesediaannya untuk ikut berpartisipasi dalam penelitian ini melalui wawancara penelitian. Tujuan wawancara adalah untuk mendapatkan gambaran mengenai kondisi kekinian (eksisting condition) Kampung Nelayan dari perspektif masyarakat. Pada kunjungan awal, penulis melakukan wawancara informal ke masyarakat (nelayan). Wawancara ini dilakukan mengingat mereka melakukan aktifitas perikanan, namun tidak keberatan menjawab pertanyaan penulis dalam rangka pencarian informasi/data ke masyarakat. Terdapat 9 (sembilan) anggota masyarakat yang terdiri dari 3 (tiga) orang laki-laki (nelayan) dan 6 (enam) orang isteri nelayan yang juga bekerja di sektor perikanan untuk membantu suami mereka. Wawancara ke kepala desa setempat juga memberikan informasi kepada penulis mengenai gambaran Kampung Nelayan.

Data dalam penelitian ini juga diperoleh melalui observasi dengan catatan penelitian selama melakukan kunjungan. Penulis melakukan kunjungan, pencatatan observasi di lapangan khususnya yang berkaitan dengan aktifitas masyarakat. Penentuan sampel (informan) dalam penelitian ini adalah purposive sampling dengan tetap memerhatikan kesediaan masyarakat untuk menjadi informan penelitian. Data kualitatif yang diperoleh dianalisis dengan prinsip analisis data kualitatif. Penulis menerapkan prinsip analisis data secara tematik dalam menyajikan hasil analisis data penelitian.

\section{HASIL DAN ANALISIS}

\section{Gambaran Umum Kampung Nelayan Tanjung Binga, Belitung}

Kampung Nelayan atau Dusun Pantai Selatan Tanjung Binga di Kecamatan Sijuk, Kabupaten Belitung adalah lokasi dimana mayoritas penduduknya melakukan aktifitas nelayan. Nama Kampung Nelayan nampkanya tepat karena kehidupan penduduk sangat tergantung pada hasil laut melalui tangkapan ikan para nelayan. Aksesibilitas menuju Kampung Nelayan sangat mudah dijangkau dari Kota Tanjungpandan. Perjalanan dapat ditempuh lebih kurang $20 \mathrm{~km}$ dengan transportasi darat (mobil pribadi) dengan jalanan yang beraspal. Profesi nelayan diturunkan oleh generasi pendahulu dan hingga saat ini, profesi tersebut mampu memenuhi kehidupan perekonomian masyarakatnya. Dari hasil wawancara penulis, para nelayan yang tinggal di Kampung Nelayan berasal dari Sulawesi Selatan, suku Bugis yang merantau dan melanjutkan kehidupan mereka di Kampung Nelayan Tanjung Binga. Wawancara informal dengan para nelayan dan isteri nelayan (kode; informan 1, 2, 3 dan 4) dilaksanakan di sekitar rumah penduduk dan berdekatan dengan lokasi penjemuran ikan hasil tangkapan nelayan. Wawancara penelitian 
dilaksanakan pada tanggal 25 Oktober 2020 dengan terlebih dahulu menyampaikan kepada penduduk mengenai latar belakang penulis dan tujuan kunjungan penulis.

Penduduk setempat menyampaikan bahwa kehidupan sebagai nelayan telah mampu memberikan kesejahteraan masyarakatnya dari sisi ekonomi. Namun, kehidupan sebagai nelayan cenderung membuat masyarakat tergantung pada alam (laut) sebagai sumber kehidupan. Penduduk setempat memberikan contoh bahwa ada anggota keluarga yang tidak ingin melanjutkan pendidikan ke jenjang yang lebih tinggi karena penghasilan yang didapatkan sebagai nelayan sudah menjanjikan bagi kehidupan mereka. Pada kondisi dimana nelayan mampu mendapatkan tangkapan yang banyak, maka nilai ekonomis yang mereka peroleh mampu mengalahkan jumlah pendapatan dari jenis pekerjaan lain. Hal ini menjadi alasan bagi para kelompok pemuda untuk memilih nelayan sebagai profesi dibandingkan mencari pekerjaan lain.

\section{Peluang dan Potensi Pariwisata Kampung Nelayan}

Salah satu potensi yang dapat menjadi daya tarik wisata bagi wisatawan adalah aktifitas nelayan yang mengelola hasil tangkapan ikan agar dapat dijual kembali. Ketika kunjungan ke Kampung Nelayan, penulis mengamati proses pengolahan ikan teri yang akan dikeringkan dengan proses pencucian air garam. Selanjutnya, ikan-ikan tersebut akan dijemur dengan memanfaatkan wilayah pesisir yang telah dibuat untuk area penjemuran ikan.

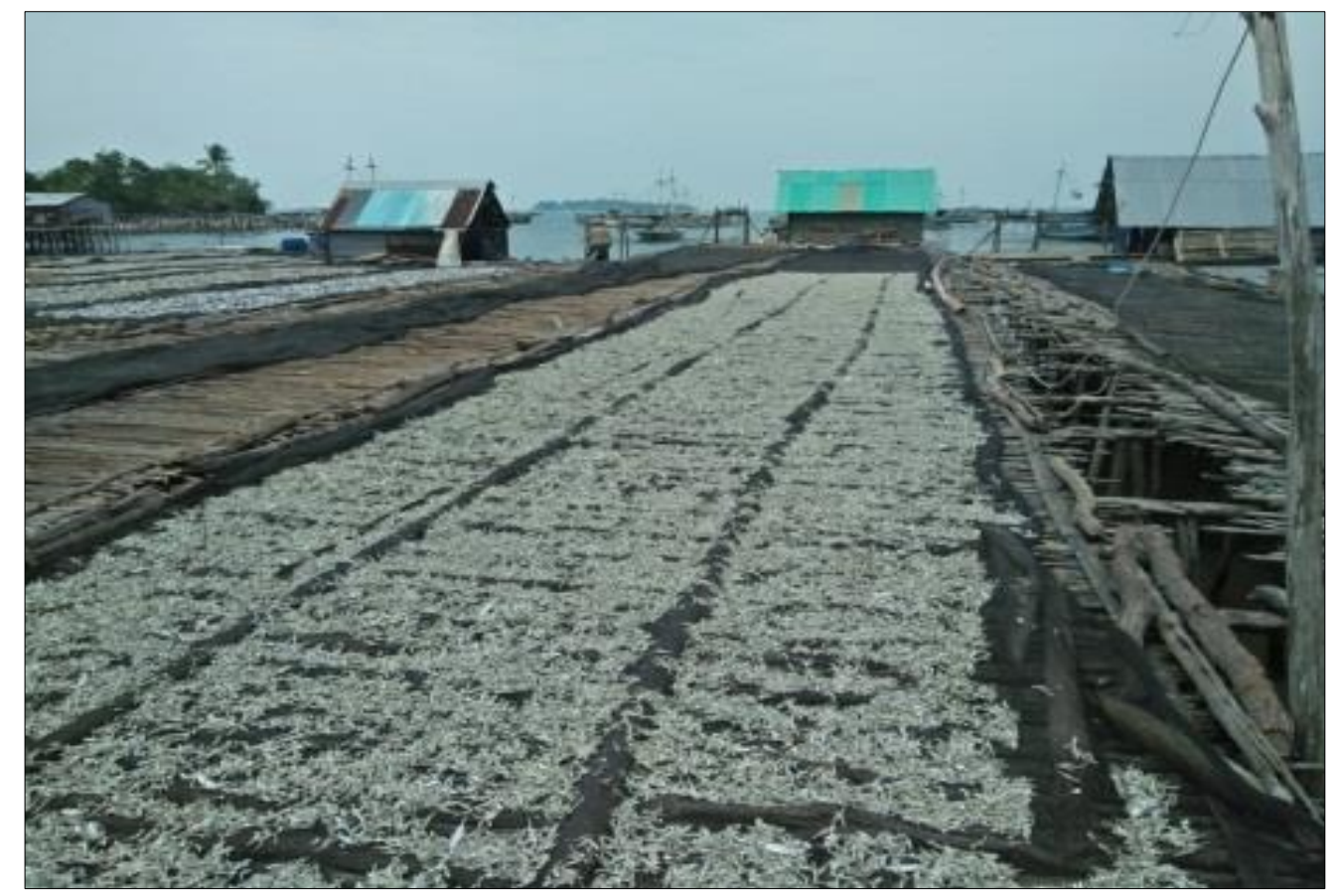

Gambar 1. Kampung Nelayan di Tanjung Binga, Kabupaten Belitung Sumber: Penulis, 2019

Gambar 1 menunjukkan lokasi penjemuran ikan hasil tangkapan nelayan. Lokasi pesisir dimanfaatkan oleh masyarakat untuk menjemur ikan yang selanjutny akan menjadi komoditi nilai tambah yang akan dijual ke wilayah-wilayah di Indonesia, bahkan diekspor ke luar negeri. Bagi penduduk Kampung Nelayan, banyak wisatawan mancanegara yang datang melihat aktifitas mereka dan mengambil gambar sebagai bukti kunjungan mereka ke kampung tersebut. Aktifitas 
nelayan ini menjadi pesona bagi wisatawan yang senang akan eksplorasi aktifitas tradisional masyarakat.

Penduduk di Kampung Nelayan menawarkan aktifitas mengikuti kegiatan nelayan mulai dari persiapan perjalanan ke laut, penangkapan ikan di laut hingga proses penjualan kembali ikan tersebut. Penduduk tidak meminta bayaran kepada penulis, semata-mata untuk menunjukkan bagaimana kehidupan nelayan dalam menangkap ikan. Penawaran tersebut dapat dipahami sebagai bentuk penghargaan kepada tamu yang datang karena semangat ingin mempelajari kehidupan masyarakat nelayan serta menghargai aktifitas para nelayan. Selain itu, penduduk setempat merasa bangga dengan mata pencaharian mereka karena profesi nelayan telah memberikan mereka cara untuk bertahan hidup. Kehidupan sebagai nelayan menjadi pilihan karena alam memberikan mereka hasilnya dan kemampuan sebagai nelayan yang diturunkan secara turun temurun memungkinkan mereka untuk menikmati kehidupan mereka sebagai nelayan.

Dalam konteks pariwisata, proses dari pekerjaan penduduk dalam menangkap ikan dan memprosesnya menjadi ikan yang siap jual adalah peluang untuk menarik wisatawan. Terdapat beberapa kelompok wisatawan yang mungkin dapat berkunjung untuk melihat aktifitas tersebut. Wisatawan atau pengunjung yang memiliki motivasi pendidikan (studi) dan penelitian. Banyak isu yang dapat diangkat dalam rangka melakukan eksplorasi Kampung Nelayan dari beragam perspektif penelitian. Bagi pebelajar, kunjungan ke Kampung Nelayan dapat menjadi salah satu cara untuk memahami sosial budaya masyarakat Indonesia yang dikenal sebagai negara maritim. Kehidupan maritim sesungguhnya dapat diketahui dengan melakukan kunjungan ke Kampung Nelayan. Namun, jenis wisata pendidikan belum digarap sebagai peluang untuk mewujudkan Kampung Nelayan sebagai tujuan wisata pendidikan.

Pariwisata budaya adalah jenis wisata yang layak untuk dikembangkan di Kampung Nelayan. Penduduk yang bekerja sebagai nelayan adalah mayoritas suku Bugis yang mendiami wilayah tanah melayu yang juga memiliki karakteristik budaya yang unik. Penulis mencatat pentingnya melestarikan budaya Bugis dan budaya Melayu yang menjadi salah satu kekayaan budaya Indonesia yang perlu dilestarikan. Pengemasan pariwisata budaya dengan mengajak generasi muda untuk menjadi bagian dari pelestarian budaya Bugis dan Melayu seperti tarian tradisional, alat musik tradisional, cerita rakyat yang bernilai edukasi dan kehidupan tradisional masyarakat sebagai nelayan dan kemaritiman. Pariwisata budaya adalah jenis wisata yang dapat menarik pencinta budaya baik wisatawan mancanegara maupun domestik.

\section{Peran dan Fungsi Masyarakat Kampung Nelayan dalam Mewujudkan Desa Wisata}

Kampung Nelayan di Tanjung Binga belum menjadi desa wisata yang secara resmi memiliki struktur organisasi yang mengatur dan mengelola desa wisata. Namun, masyarakat menyadari dan menyambut baik kedatangan wisatawan. Hal ini telah disampaikan oleh informan bahwa kunjungan wisatawan ke Kampung Nelayan umumnya untuk melihat aktifitas masyarakat sebagai nelayan. Kunjungan wisatawan tersebut memungkinkan pengelolaan desa dalam konsep pariwisata berbasis masyarakat dan desa wisata. Keramahtamahan penduduk merupakan modal utama bagi suatu desa karena mereka akan berhadapan dengan tamu yang datang untuk melihat secara langsung. Namun, pariwisata juga menekankan pentingnya pelibatan masyarakat sebagai anggota yang mengelola langsung potensi maritim yang dimiliki.

Kondisi faktual di Kampung Nelayan menunjukkan bahwa tingkat partisipasi masyarakat dalam kegiatan pariwisata masih dalam tahap penjajakan (eksplorasi) peluang untuk menjadi desa wisata. Partisipasi masyarakat dikategorikan sebagai kategori pasif atau bahkan belum ada karena 
mereka hanya menjadi tujuan kunjungan, belum terorganisir sebagai sebuah desa wisata. Penduduk hanya menerima kunjungan wisatawan tanpa mengetahui apa yang harus dilakukan ketika wisatawan berkunjung. Manfaat ekonomi dari kegiatan pariwisata belum dilirik oleh penduduk setempat sehingga partisipasi masyarakat berpeluang untuk ditingkatkan sebagai pengelola potensi wisata.

Dalam konteks sosial kemasyarakatan, peran masyarakat dilihat dari perannya sebagai anggota masyarakat sekaligus sebagai tokoh masyarakat dengan posisinya masing-masing. Peran dalam konteks pariwisata belum dapat diuraikan secara jelas mengingat mereka hanya menjalankan perannya masing-masing tanpa memandang pariwisata sebagai bagian dari kehidupan mereka. Karena itu, penelitian ini membagi 3 (tiga) peran masyarakat jika desa wisata dijalankan. Anggota masyarakat yang dapat aktif dalam kegiatan pariwisata dapat dikategorikan sebagai peran inisiator atau penggagas kegiatan desa wisata. Penduduk dalam kategori ini dapat berasal dari tokoh masyarakat, masyarakat umum ataupun kalangan pemuda. Desa wisata membutuhkan peran inisiator dari masyarakat untuk memulai suatu aktifitas pariwisata.

Peran kedua adalah sebagai executor sekaligus sebagai organizer. Organisasi kelompok sadar wisata seharusnya dibentuk sebagai wadah untuk menjalankan desa wisata. Peran executor ditunjukkan melalui keterlibatan penduduk dalam organisasi Pokdarwis. Pokdarwis dapat dijalankan dengan dua tahap, pertama, inisiasi dari anggota masyarakat. Kedua, Pokdarwis diiniasiasi oleh pemerintah daerah dan ditindaklanjuti oleh masyarakat sebagai executor. Peran ketiga adalah sebagai evaluator yang bertugas untuk melakukan evaluasi terhadap program kerja yang dijalankan oleh Pokdarwis. Penduduk baik yang terlibat secara langsung dalam Pokdarwis maupun yang bukan anggota Pokdarwis menjalankan peran evaluator sebagai wujud tanggung jawab untuk mendorong dan membantu masyarakat menyelenggarakan kegiatan kepariwisataan.

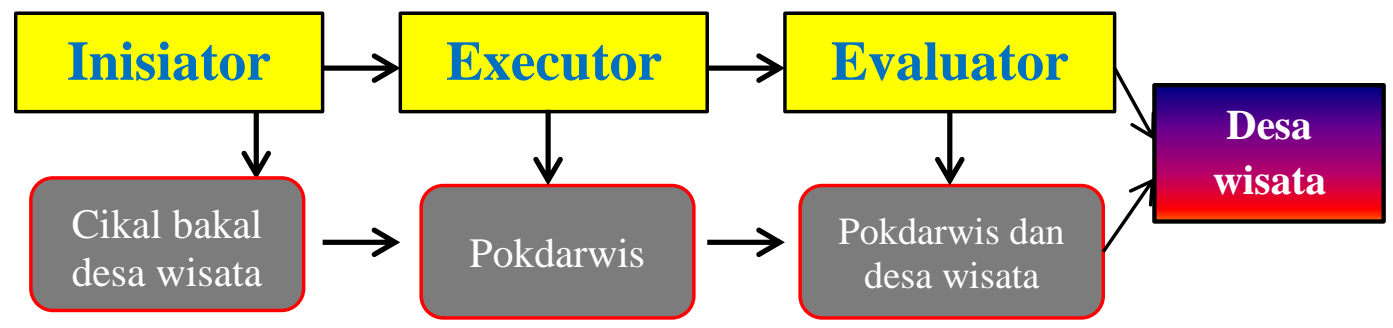

Bagan 1. Peran masyarakat di Kampung Nelayan dalam mewujudkan desa wisata

Sumber: Penulis, 2020

Bagan 1 menunjukkan skema peran masyarakat dalam mewujudkan desa wisata di Kampung Nelayan, Kabupaten Belitung. Bagan tersebut terdiri dari peran inisiator, executor dan evaluator. Setiap peran dijelaskan dengan penjelasan singkat mengenai peran dari anggota masyarakat.

Penelitian ini merekomendasikan 4 (empat) tahap atau fungsi masyarakat yang dapat diterapkan agar Kampung Nelayan dapat diwujudkan sebagai Desa Wisata unggulan. Tahap atau fungsi masyarakat didasarkan pada konsep yang dikemukakan oleh Wall (2000). Usulan tahap atau fungsi masyarakat pada penelitian ini merupakan kajian penulis dalam melihat peluang (potensi) dan kondisi kekinian yang ada di kampung tersebut. 


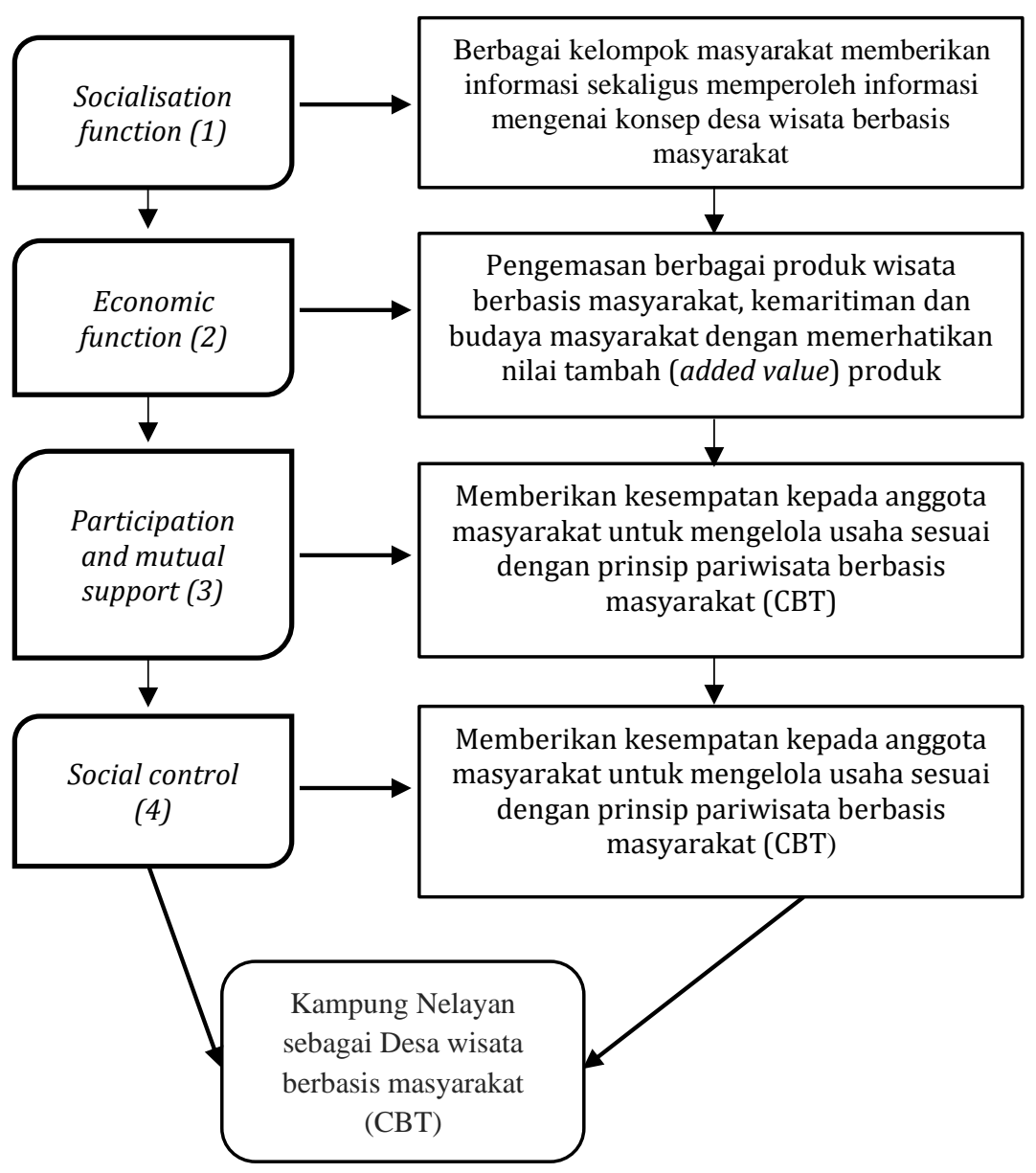

Bagan 2. Tahap penerapan fungsi masyarakat dalam mewujudkan desa wisata di Kampung Nelayan

Sumber: Penulis, 2020

\section{Tahap atau fungsi sosialisasi (socialisation function)}

Fungsi sosialisasi diartikan sebagai tugas berbagai kelompok masyarakat untuk memberikan informasi sekaligus memperoleh informasi mengenai konsep desa wisata berbasis masyarakat. Kesibukan anggota masyarakat sebagai nelayan memungkinkan sulitnya organisasi atau lembaga luar untuk masuk memberikan sosialisasi informasi. Namun, terdapat masa atau waktu dimana kelompok pemuda dan anggota masyarakat dapat menghadiri kegiatan sosialisasi tanpa mengganggu aktifitas mereka sebagai nelayan. Socialisation function dapat dilakukan oleh pemerintah daerah, institusi pendidikan tinggi, lembaga swadaya masyarakat, ataupun nongovernment organisation dengan fokus pada pemahaman masyarakat mengenai konsep desa wisata berbasis CBT. Socialisation function memiliki makna luas karena pihak luar (external parties) bukan satu-satunya kelompok masyarakat yang dapat terlibat. Namun, pihak internal yakni para tokoh masyarakat, pemuda dan kalangan pelajar dapat menjadi inspirator untuk memberikan fungsi penjalsan ke masyarakat.

\section{Tahap atau fungsi ekonomi (economic function)}

Economic function adalah tahap kedua yang dapat diterapkan di Kampung Nelayan. Penduduk setempat telah menghasilkan ikan melalui hasil tangkapan mereka dan diproses untuk 
dijual. Hal ini menunjukkan bahwa economic function yang dijalankan oleh penduduk di Kampung Nelayan telah berjalan. Namun, penduduk dapat lebih meningkatkan peran dan fungsinya pada tahap economic function jika ada alternatif lain untuk meningkatkan perekonomian. Kunjungan wisatawan dapat dimanfaatkan dengan penyediaan paket wisata (tour packages) bagi wisatawan. Penawaran masyarakat ke wisatawan melalui kegiatan sebagai nelayan sebagaimana diuraikan pada bagian sebelumnya adalah contoh paket wisata meskipun belum dikelola secara terstruktur. Tahap economic function dapat diwujudkan dalam berbagai bentuk, misalnya, pengemasan berbagai produk ikan dengan memerhatikan nilai tambah (added value), tidak hanya dijual kepada pengumpul yang datang.

\section{Tahap atau fungsi partisipasi dan saling mendukung}

Pada tahap ini, penduduk akan mulai melihat manfaat yang diperoleh ketika Kampung Nelayan dikembangkan sebagai desa wisata. Umumnya, masyarakat di suatu destinasi membutuhkan aktifitas perekonomian untuk mempertahankan hidupnya. Kehidupan sebagai nelayan adalah aktifitas musiman, hasil tangkapan sangat tergantung pada musim dan kondisi alam. Menurut penduduk setempat, mereka memaksimalkan tangkapan ikan di musim ketika banyak tangkapan ikan. Nelayan atau penduduk membutuhkan aktifitas tambahan yang memungkinkan mereka mendapatkan kesempatan untuk berbisnis, salah satunya melalui kegiatan pariwisata. Pengelolaan desa wisata memberikan kesempatan kepada anggota masyarakat untuk mengelola usaha sesuai dengan prinsip pariwisata berbasis masyarakat (CBT). Anggota masyarakat lain seharusnya mendukung satu sama lain karena konsep desa wisata tidak dapat diwujudkan dan dikembangkan tanpa dukungan seluruh anggota masyarakat.

\section{Tahap atau fungsi kontrol sosial (social control)}

Fungsi kontrol (social control) dapat dimaknai sebagai monitoring kegiatan yang dijalankan oleh penduduk di Kampung Nelayan. Kepengurusan yang dibentuk pada desa wisata seharusnya memasukkan unsur penasehat sekaligus pengontrol agar kepengurusan melaksanakan tugas sesuai dengan fungsi manajemen yang bertanggung jawab. Fungsi kontrol adalah salah satu aspek penting dalam mengembangkan desa wisata. Jika suatu kelompok desa wisata menggunakan dana yang dikelola secara kelompok, maka fungsi control akan membantu dalam mewujudkan transparansi pemanfaatan dan pertanggungjawaban dana.

\section{E. SIMPULAN}

Gagasan desa wisata telah mulai diterima sebagai sebuah konsep yang tepat untuk mengembangkan potensi pariwisata yang dimiliki oleh suatu destinasi. Desa wisata menjadi pilihan bagi kebanyakan desa di Indonesia karena mampu mendorong peran berbagai anggota masyaraat untuk aktif terlibat dalam kegiatan pariwisata. Keberhasilan pengelolaan desa wisata tidak terlepas dari keinginan penduduk di desa untuk berpartisipasi dalam kegiatan pariwisata. Kampung Nelayan di Tanjung Binga, Kabupaten Belitung juga memiliki peluang untuk menjadi desa wisata sebagaimana desa-desa lain yang ada di Indonesia. Untuk mewujudkannya, tentu membutuhkan peran dari berbagai stakeholder. Penelitian difokuskan pada bagaimana mengoptimalkan peran masyarakat sebagai insiator sekaligus pelaku pariwisata, selaian perlu adanya dukungan dari anggota masyarakat lain (eksternal) dari desa itu sendiri.

Eksistensi Kampung Nelayan yang termuat dalam promosi Kabupaten Belitung menunjukkan bahwa desa wisata atau wisata pedesaan dapat menjadi pilihan wisatawan untuk melakukan eksplorasi wisata. Penelitian ini telah merekomendasikan tahap-tahap fungsi masyarakat dalam rangka menunjang 
terwujudnya Kampung Nelayan sebagai desa wisata. Terdapat berbagai pilihan konsep dalam mengupayakan pelibatan masyarakat dalam kegiatan pariwisata, salah satunya pendekatan pariwisata berbasis masyarakat (CBT). Namun, konsep ini tidak dapat terwujud tanpa melalui suatu proses yang dijalankan secara bersama-sama oleh masyarakat. Karena itu, usulan dalam penelitian ini perlu ditindaklanjuti dengan upaya bersama baik melalui peran external stakeholder maupun internal stakeholder. Konsep CBT dan desa wisata perlu dikaji dalam berbagai perspektif. Penelitian ini belum mengkaji persepsi pemerintah mengenai rencana implementasi CBT dan desa wisata di Kampung Nelayan. Karena itu, penulis merekomendasikan perlunya penelitian lanjutan untuk memahami faktor pendukung dan penghambat pelaksanaan desa wisata berbasis masyarakat dari perspektif pemerintah daerah.

\section{DAFTAR REFERENSI}

Aas, C., Ladkin, A., \& Fletcher, J. (2005). Stakeholder collaboration and heritage management. Dalam D. J. Timothy (Ed.), Managing heritage and cultural tourism resources: critical essays (Vol. 1, pp. 1-22). Farnham: Ashgate.

Beeton, S. (2006). Community development through tourism. Collingwood, Australia: Landlinks Press.

Campón-Cerro, A. M., Hernández-Mogollón, J. M., \& Alves, H. (2017). Sustainable improvement of competitiveness in rural tourism destinations: The quest for tourist loyalty in Spain. Journal of Destination Marketing \& Management, 6, 252-266.

Dewi, M.H.U., Fandli, C., \& Baiquni, M. (2013). Pengembangan desa wisata berbasis partisipasi masyarakat lokal di Desa Wisata Jatiluwih Tabanan, Bali. Kawistara, 3(2), 117-226.

Derek Hall, Morag Mitchell and Lesley Roberts. Tourism and the countryside: Dynamic relationships. Hal. 3-18. In D. Hall, L. Roberts, \& M. Mitchell (Eds.), New directions in rural tourism. New York: Routledge.

Embacher, H. (2016). Strategy Formulation in Rural Tourism- An Integrated Approach. In D. Hall, L. Roberts, \& M. Mitchell (Eds.), New directions in rural tourism (pp. 137-151). New York: Routledge

Ezeuduji, I O., \& Rid, W. (2011). Rural tourism offer and local community participation in the Gambia. Tourismos: An International Multidisciplinary Journal of Tourism, 6(2), 187-211.

Farrell, H., \& Russell, S. (2011). Rural tourism. Dalam P. Robinson, S. Heitmann, \& P. Dieke (Eds.), Research themes for tourism (pp. 100-113). Cambridge, USA: CABI.

Hall, C.M., \& Lew, A. (2009). Understanding and managing tourism impacts: An integrated approach. London: Routledge.

Hiwasaki, L. (2006). Community-based tourism: a pathway to sustainability for Japan's protected areas. Society and Natural Resources: An International Journal, 19(8), 675-692.

Junaid, I., Yusuf, M., Salam, N., Salim, M.A.M., Fauziah, A.N. (2020). Pengelolaan Kampung Nelayan sebagai desa wisata di Kabupaten Majene, Sulawesi Barat. Pusaka (Journal of Tourism, Hospitality, Travel and Business Event), 2(1), 17-24.

Junaid, I., \& Salim, M.A.M. (2019). Peran organisasi tata kelola dalam pengelolaan Desa Wisata Nglanggeran, Yogyakarta. Pusaka (Journal of Tourism, Hospitalit, Travel and Business Event), $1(1), 1-7$.

Kibicho, W. (2008). Community-based tourism: A factor-cluster segmentation approach. Journal of Sustainable Tourism, 16(2), 211-231.

Manyara, G., \& Jones, E. (2007). Community-based tourism enterprises development in Kenya: an exploration of their potential as avenues of poverty reduction. Journal of Sustainable Tourism, 15(6), 628-644.

Matarrita-Cascante, D. (2010). Changing communities, community satisfaction, and quality of life: A view of multiple perceived indicators. Social Indicators Research, 98(1): 105-27.

Murphy, P.E. (1985). Tourism: A community approach. New York: Methuen.

Murdoch, J. (2003) The Differentiated Countryside. London: Routledge. 
Nicely, A., \& Sydnor, S. (2015). Rural tourism development: Tackling a culture of local nonparticipation in a postslavery society. Journal of Travel Research, 54(6), 717-729. doi: 10.1177/0047287514535846

Petrzelka, P., Krannich, R.S., Brehm, J. \& Trentelman, C.K. (2005). Rural tourism and gendered nuances. Annals of Tourism Research, 32(4), 1121-1137.

Priyanto, \& Safitri, D. (2016). Pengembangan potensi desa wisata berbasis budaya tinjauan terhadap Desa Wisata Di Jawa Tengah. Jurnal Vokasi Indonesia, 4(1), 77-84.

Putra, A. S. (2013). Pola kemitraan pariwisata dalam manajemen atraksi Desa Wisata Pampang Kota Samarinda. Jurnal Nasional Pariwisata, 5(3), 189-200.

Sharpley, R. (2002). Rural tourism and the challenge of tourism diversification: The case of Cyprus. Tourism Management, 23, 233-244.

Sunarjaya, I. G., Antara, M., \& Prasiasa, D. P. O. (2018). Kendala pengembangan Desa Wisata Munggu, Kecamatan Mengwi, Badung. Jurnal Master Pariwisata, 4(2), 215 - 227.

Zapata, M. J., Hall, C. M., Lindo, P., \& Vanderschaeghe, M. (2011). Can community-based tourism contribute to development and poverty alleviation? Lessons from Nicaragua. Current Issues in Tourism, 14(8), 725-749. 